\title{
Courting Don Quixote. An Aulic Frame of Reading
}

By: Ignacio Lopez Alemany

Alemany, I. L. “Courting Don Quixote. An Aulic Frame of Reading.” Cervantes: Bulletin of the Cervantes Society of America 33.2 (2013): 49-70.

Made available courtesy of Cervantes Society of America: $\underline{\text { http://cervantessociety.com/ }}$

***(C) Cervantes Society of America. Reprinted with permission. No further reproduction is authorized without written permission from Cervantes Society of America. This version of the document is not the version of record. Figures and/or pictures may be missing from this format of the document. $* * *$

\begin{abstract}
:
Despite the current success of aulic studies in early modern history, the court did not exist as a research topic on its own until well into the 1980s. Before then, historians tried to compile all the information they could with the hope of being able to reconstruct a "perfect" narration of their national history. In the twentieth century, it was argued that a collection of data reflects not only objective information, but also the personality, interests, goals, and beliefs of the collector and his or her society. The ideal of "Total History"--the aspiration to write an indisputable and objective narration of cultures and nations has disintegrated. Historical studies have since diversified into multiple circumstantial, inapprehensible and sub-theoretical pieces. It is in this context that the subfield of "court history" has been able to grow in recent decades. In many instances, court history studies what happens behind the scenes of major historical events, and therefore its findings and achievements were often neglected of diminished by the traditional notion of history. In court history, secrets and rumors, games, friendships, and personal preferences are more important than facts, battles, and offices.
\end{abstract}

Keywords: aulic | court history | historical studies

Article:

***Note: Full text of article below 


\section{Courting Don Quixote: An Aulic Frame of Reading}

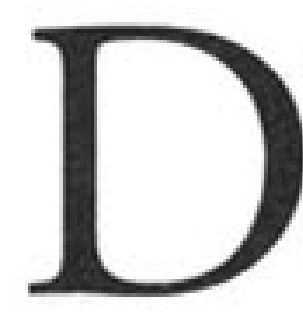

ESPITE THE CURRENT SUCCESS of aulic studies in early modern history, the court did not exist as a research topic on its own until well into the r980s. Before then, historians tried to compile all the information they could with the hope of being able to reconstruct a "perfect" narration of their national history. In the twentieth century, it was argued that a collection of data reflects not only objective information, but also the personality, interests, goals, and beliefs of the collector and his or her society. The ideal of "Total History" - the aspiration to write an indisputable and objective narration of cultures and nations has disintegrated. Historical studies have since diversified into multiple circumstantial, inapprehensible and subtheoretical pieces. It is in this context that the subfield of "court history" has been able to grow in recent decades. In many instances, court history studies what happens behind the scenes of major historical events, and therefore its findings and achievements were often neglected or diminished by the traditional notion of history. In court history, secrets and rumors, games, friendships, and personal preferences are more important than facts, battles, and offices.

Because of court history's late development, we still lack an extensive bibliography on Miguel de Cervantes's interactions with the historical courts and patrons to whom he has been connected, much less on how his literary work relates to the court as a socio-historical institution. This does not mean that aulic studies has been completely neglected by Cervantine scholarship. A fairly large number of 
Cervantes scholars during the nineteenth and early twentieth centuries examined the connection between Cervantes's work and the Habsburg court. However, this was not done with the intention of examining the actual relation between his prose and the Spanish royal household, but more as a sort of epic quest to find the hidden identity of Alonso Fernández de Avellaneda, the pseudonymous author of the false Don Quixote that was published in 1614, shortly before the publication of Cervantes's own second part.

It is not the intention of this article to continue an examination of the true identity of Avellaneda or the role he may have played at the Spanish court. The purpose, rather, is to offer an aulic perspective from which to read and interpret Don Quixote as it relates to and engages in a discussion about the court as a sociological entity during the reign of Philip III. This essay departs from the recent scholarly trend that views the court as a social mixture of nobility and bourgeoisie, laymen and churchmen, courtiers and officials to examine the complex dynamics of patronage and clientèle, and the impact of these various constituencies in the construction of new sets of norms of behavior and ethical codes that differ from those of the warrior society of the knighthood.

An aulic reading of Don Quixote is of special interest because early modern courtiers througout Europe saw themselves as the direct descendants of the medieval knights, and therefore as legitimate heirs to their values and privileges. In other words, courtier-knights eventually thought of themselves as modern versions of the earlier class of warriorknights. The symbol of the knight was his armor, which was the external projection of his power as both furtitudo and auctoritas. With this in mind, it is not very surprising that very early on the virtues that the knight was to embody were associated and represented by the different pieces of his suit of armor. Ramón Llull, in part five of his Libro de la Orden de Caballeria (I28I) says of the knight's helmet:

[A] sí como el yelmo defiende la cabeza, que es el miembro más alto y principal que posee el hombre, la vergüenza defiende al caballero $[. .$.$] para que no se incline hacia los actos viles y para que la$ 
nobleza de su corazón no se rebaje a la maldad ni al engaño ni a ninguna mala costumbre. (9I)

The helmet, then, is not only a physical protection for the head, but also a spiritual reminder of the noble and honest behavior that is expected from every knight. Each part of the armor, in Llull's description, carries a similar symbolic meaning. In this way,

el caballero debe vencer y destruir con la espada a los enemigos de la Cruz ... la lanza se le da al caballero para significar la verdad, pues la verdad es recta y no torcida ... loriga significa castillo y muralla contra los vicios y falsedades... para significar el noble corazón del caballero, en el que no pueden entrar traición, orgullo, deslealtad ni ningún otro vicio. (90-9I)

Luis Milán, in El cortesano (156I), draws a natural connection between Roman military heroes, medieval warrior-knights, and modern courtier-knights, as being distinct diachronic manifestations of the same nature. According to Milán, the armor of a modern-day knight, to be a complete set, ought to have the following parts:

[U]n yelmo de consideración, [para] que sea bien considerado en dichos y hechos, y una goleta de temperancia, [para] que no coma sino para bivir y no biva para comer [...] y un peto animoso, que ofrezca su pecho a qualquier contrario, para reparo de quien justamente lo avra menester. Con un bolante diligente porque no se pierda lo bien hecho por negligencia, y un spaldar de çufrimiento, para que traiga a sus espaldas la carga que deve el cavallero. Y la doble pieça de esperar, para que spere qualquier encuentro que fuere obligado. $\mathrm{Y}$ unos braçales de essecuciones para que essecute defendiendo lo bueno y ofendiendo lo malo en su caso y lugar. Y unos guardabraços defensivos para defender los braços de la república [...] y unas manoplas liberales, para que tenga manos abiertas para dar la vida a quien debe, y un arnés de piernas bien 
andantes, para que anden por passos mostrando el passo para passar a él y a otros a la verdadera vida, pues el cavallero debe passearse por este mundo dando exemplo y leyes de bien bivir. (A2r-A2v)

Milán's new allegorical interpretation of the knight's armor is an attempt to replace the most significant virtues of a warrior society-nobility, valor, and fortitude - with those of a courtesan life governed by a different set of moral attributes in which consideration, temperance, cheerfulness, longsuffering, diligence, and generosity are emphasized. ${ }^{1}$ These aulic ideals are not necessarily in conflict with the ones embodied previously by the warrior-knight, but there is no doubt that the arrival of a progressive courtly sublimation of physical force brought with it a different hierarchy of values to be represented by high society. And just as the pieces of armor of Don Quixote's great-grandparents are covered by "orín y llenas de moho, luengos siglos había que estaban puestas y olvidadas en un rincón," so too the virtues that these arms once represented now seem to have been forgotten and replaced by new aulic ideals (I.I:75).

Norbert Elias explains that this "civilizing process" occurs "step by step, [as] a warrior nobility is replaced by a tamed nobility with more muted affects, a court nobility. Not only within the Western civilizing process, but as far as we can see within every major civilizing process, one of the most decisive transitions is that of warriors to courtiers" (Civilizing 389). According to Elias, in the modern Machiavellian court, the ultimate goal of politics is not justice or the welfare of the country, but the attainment and retention of power. As a natural consequence, courtiers follow a different logic, distancing themselves from moral or religious premises. When the government of the state is placed on courtiers' shoulders, power is given to a group that seeks personal and individual interest above all else. Selfishness, dissimulation, and cau-

I Milán does not include here "discreción," a concept which will gain importance in the latter part of the sixteenth and early seventeenth centuries. This term was meticulously defined by Damasio de Frías y Balboa - a writer praised by Cervantes in "El Canto de Calíope"-in a monographic dialogue of his Diálogos de diferentes materias (1579). I would like to thank Ryan Schmitz for drawing this to my attention. See Schmitz. 
tion - rather than nobility, valor, and fortitude-become the new and desired virtues of the courtier-knight (Court II3).

In the particular context of Don Quixote, some aspects of the story of the knight-errant might be better understood if we take into consideration how the novel represents the court as a social institution in itself, and in the light of the historical Spanish court of the time. The first part of Don Quixote (1605) was published during the beginning years of the reign of Philip III, who succeeded his father in 1598. The last years of Philip II were characterized by the King's severe asceticism and distrust of his court and advisors. He would only receive and be seen by select families of the aristocracy, and even then, he did not meet them frequently or for extended periods of time (Bouza 53). The second part of Don Quixote (1615) came out when the reign of Philip III was at its height. This period marked a shift from a court society that based its privileges on the merits of the battlefield to one that sought to gain the favor of the King at the palace. With the consolidation of the reign of Philip III came a wave of relief from the previous austerity: playhouses re-opened and the King and his court sponsored continuous celebrations, games, tourneys, farces, etc. The second part of Don Quixote certainly reflects this new spirit at the Spanish court, particularly during Don Quixote's long stay at the Duke's palace. In the transition from the first part to the second we also see how the novel exchanges knighthood for courtierhood as the moral target of its criticism.

Not only had the court changed from one Don Quixote to the next; Cervantes had changed as well. The first part was written by an author with very little commercial success, who resented the pettiness of his reward for having served as a solider in the King's army at the Battle of Lepanto. The Cervantes of the second part, on the contrary, had enjoyed enormous literary success as evidenced by the translations of Don Quixote that were published in French, German, Italian, and English within just a few years of the original publication. Cervantes had seen his principal characters, Don Quixote and Sancho Panza, gain great popularity with the King and the nobility, both characters being commonly present at the most important court celebrations. 
As early as June 1605 , Valladolid celebrated the birth of the Spanish prince and future King Philip IV, with a series of "entremeses" in which one could find knights costumed as Don Quixote and Sancho Panza (Crespo 122). In 1608, an event that took place in Tudela del Duero included the character of Don Quixote as part of the public celebration and solemn entrance of the Duke of Lerma. According to the protocol for royal entrances, although Lerma was only the valido, the church hosted a religious ceremony in thanksgiving of his arrival. Around midafternoon, there was a bullfight followed by an "Aventura del caballero Don Quijote" featuring the knight-errant, and ending with a tourney of fire. This first day of celebration came to an end with a spectacle of fireworks and a "Máscara triunfal de los Nueve de la Fama" where, according to the chronicler, the Duke of Lerma himself appeared as a "mancebo hidalgo de gentil talle armado de medio cuerpo arriba con faldones y calza entera, la espada bien ceñida y un bastón de general en la mano" (García García 60-6I).

Just one year after this last celebration, on the occasion of the birth of Ferdinand of Austria on May 16, 1609, Rodrigo Calderón, count of Oliva, wrote to Diego Sarmiento de Acuńa, count of Gondomar, suggesting the organization of a "juego de cañas" in the town of Lerma to celebrate the new addition to the royal family. In that courtly competition, Rodrigo Calderón announced that he would attend the event escorted by his own servants wearing costumes that would make him look as if he were the Cid of Vivar (García García 62).

It appears that the obsession with Don Quixote had spread all over the Spanish court. The hidalgo, Don Alonso Quixano, had thought himself to be a true knight-errant, but others as notable as the Duke of Lerma and the Count of Oliva were playing the role of famous and legendary knights as well. And if Cervantes's humble hidalgo imagined giants where there were only windmills, the Spanish court, with far more resources, had been for years building complicated stages for their chivalric illusions. According to Cabrera de Córdoba’s account, in 1602, the Duke of Lerma prepared a celebration with adventures and games that would have delighted Don Quixote: 
En el cuarto donde posa en Palacio, en ciertos aposentos y galerías que tienen allí muy buenos y estuvieron bien aderezados; y en la galería principal había dos grutas cuadradas de muy buena invención con diversas cosas y peregrinas, y espejos que hacían dos vistas de los que estaban dentro y fuera de ellos, y en la una había una seńora Margarita [la reina] con su dragón que echaba fuego y humo de pastillas por la boca, y juntamente había un molino de viento y una fuente que salía de una peña, y muchas luces en diversas formas. (Ferrer Valls I23)

And, if in the fifteenth and sixteenth centuries the romances of chivalry influenced the behavior and entertainment of the court, how can we know for sure when Cervantes is mocking the already ailing romance of chivalry and when his work is a caricature of the noble courtiers who pretended to be knights? Or does he address both at the same time? If the books of chivalry and the customs and habits of the court influence and mimic each other, how can we be sure when we are laughing at one and not the other? And who is more insane, the man who fights a windmill, or the one who fabricates a mechanical tournament? The one who believes himself to be a knight-errant or the one who pretends to be the Cid of Vivar?

The second part of Don Quixote informs its readers of the cultural relevance of the novel's first part, as do the very characters of Don Quixote in I6I5. They prove to be familiar not only with its popular stories, but also with the apocryphal continuation published under the pseudonym of Avellaneda, who from very early on was believed to be a courtier of the household of King Philip III. Modern researchers have suggested that Avellaneda could have been any number of authors, including Bartolomé Leonardo de Argensola, Fray Luis de Aliaga, Francisco de Quevedo, Lope de Vega, and the Duke of Sessa (Crespo 107). Regardless of his true identity, what matters is that Avellaneda does not make Don Quixote a knight who is concerned with the pursuit of justice, but rather one who desires a stable position at the royal 
court. In this way, and unlike Cervantes, Avellaneda aligns his character with the reality of the aspirations of the time.

Biographically, Cervantes also changed from I605 to I6I5 with regard to his social behavior, if not also in his own character. While he certainly had an irreverent spirit in the years that preceded the publication of the first part (Close lxxix), in the years that followed, he became much more integrated into the ethos of post-Tridentine Spain. In I609, Cervantes joined the lay congregation of Slaves of the Sacred Sacrament and in 1613 , shortly before completing the second part, he also joined the Third Order of Saint Francis. These affiliations made him all the more sensitive to Pauline approaches to religion and government, a worldview that emphasizes ethics over doctrine, ritual, and civil laws. Michael Armstrong-Roche has carefully studied the effect that this perspective had on Cervantes's literary production.

The moral consideration of the court in Don Quixote certainly changed in the ten years that passed between part one and part two, and this change may indeed have been influenced by Cervantes's personal biography, the integration of his characters into the celebrations of the court of Philip III, the increasing presence of the royal court itself in the life of Spaniards, and Avellaneda's representation of the apocryphal "Don Quixote" as a court-pleasing knight. In part two, the so-called "novela de los duques," as Giuseppe Grilli has called it, provides us with an aulic frame for interpreting the novel, and summarizes like no other portion of Don Quixote the new role of the Court in the shaping of the high society of the time (42).

When the first part was published, the novels of chivalry and other works of fiction were the recipients of a great deal of criticism by the Spanish Inquisition, as reflected in the scrutiny of Don Quixote's library by the priest and the barber (I.6:I09-2I). Religious authorities claimed that fictional literature created confusion among the ignorant because these authorities viewed all written books as vehicles of morality, knowledge, and history. According to many inquisitors, the public had trouble understanding the purpose of both writing and reading fiction. For Alonso Quixano's niece, reading fiction is what had turned her uncle into Don Quixote, because "estos malditos libros de ca- 
ballerías que él tiene y suele leer tan de ordinario le han vuelto el juicio" (I.5:107). Similarly, Father Jerónimo de Zurita commented, while he was working on the 1583 Spanish Index, that chivalric novels should be banned "because they are written without skill and are full of improbabilities, it is a waste of time to read them" (qtd. in Pérez I84). Father Juan de Mariana was of the same opinion, and urged the compilers of the Index to include a rule banning books of chivalry, "even if it were only to force people to read good books and genuine histories" (qtd. in Pérez 184). The inclusion of these novels in the Index was not due to alleged immorality or doctrinal errors, but merely because they were not considered good literature, with some exceptions such as Amadis de Gaula, that Mariana (as well as the priest and the barber in Don Quixote) conveniently noted (I.6:109-2I).

In the first part of Don Quixote, life at the court goes almost unnoticed and escapes strong criticism. Courtiers are never accused of being corrupt, but rather of being lukewarm with regard to their loyalty. This idea is repeated in different ways and different contexts all throughout part one, but the criticism never goes beyond the stereotypical complaint against the decadent lifestyle and softness of spirit of the courtiers. A representative example can be found in the episode in which Don Quixote explains to the shepherds the distinct behaviors expected of courtiers and knight-errants: "el paso, el regalo, allá se inventó para los blandos cortesanos; mas el trabajo, la inquietud y las armas se inventaron e hicieron para aquellos que el mundo llama caballeros andantes" (I.13:I69).

This comment does not differ much from the ones made about students or "letrados" who, in time, would receive employment and offices in the government. During their years of formation, students were forced to live with the difficulties of cold weather, lack of food, and other sacrifices, although they would eventually move up to live in a social realm that enjoyed luxurious silks from Holland, jewels, and brocades (I.37:467). However, the knight-errant, against whom the novel constantly measures the contemporary soldier, goes through more severe cases of inclement weather, hunger, and all the while confirms that soldiers are "ministros de Dios en la tierra y brazos por quien se ejecuta 
en ella su justicia," never receiving — as Cervantes never did-a just reward for their service, as courtiers and students do (I.13:I73).

In part one, Cervantes defends the warrior-knight over the courtier-knight and, therefore, the soldier over the courtier and the "letrado," considering the former as a representative of a morally superior class. Naturally, if the perfect courtier is only good for "easy living" and for accompanying the king, then his connection to a genealogy presumed to have been initiated by the Roman heroes-which is to say, the very legitimacy of his status and privileges - fades away. As a military veteran, Cervantes envisions a system that would allow for more social movement on the basis of personal merits, a system that would grant him an escape from his precarious financial situation. Within such a system, perhaps his own personal misfortune would change, and he could then receive the official post in the Americas that he had sought. He knows all too well that with the current status quo, soldiers risk their lives only to see their victories squandered at court through shallow celebrations.

James Iffland has studied the issue and has concluded that despite not centering his criticism around the court, the adventures of "the other Quixote" written by Avellaneda seem to suggest that the first part of 1605 was not only read as a book of entertainment or a mockery of chivalry romances, but also as a hostile and polemic work that questioned the court and the status of the courtiers. This seems to correspond well with the proliferation of contemporary satirical posters in which the Duke of Lerma, King Philip III's prime minister, was compared to both Don Quixote and Cervantes's contemporaries who saw in the episode of the sheep turned into two armies (in part one, chapter eighteen) a hidden symbolism that referred to specific members of the Spanish nobility (Crespo I26). Perhaps Avellaneda felt his own status as a courtier threatened by this novel and found an appropriate revenge in his apocryphal second part. In his text, Avellaneda ridicules the knighterrant, humiliating him whenever he approaches towns while pretending to be a true knight. Avellaneda's knight is just a puppet taken from one place to another without the deeply tragic spirit and often very good sense of the true Don Quixote, when he is not crazy. Avellaneda's 
Quixote is a sort of a buffoon with no soul who becomes the butt of all jokes at the royal court because of his physical appearance and clothes. He lacks the wit and the intelligence of the authentic Don Quixote and is unable to defend himself from offensive remarks (Rey Hazas I5I-52).

When Cervantes's own second part appeared, it was not the chivalric books, but the moral degeneration of the high class and of the court society of Philip III that were the major focuses of attention for the Inquisition now well into the spirit of the Catholic Reformation (Mades 73). Part two of Don Quixote reflects the changes that occurred during this time. The criticism of life at court is much more explicit and reiterative in the second part as a result of many factors, including the changes in the royal court and their moral consideration, the personal evolution of Cervantes, and the publishing of Avellaneda's Don Quixote. Alongside the brief remarks about the easy life of the palace in part one, we find a well thought-out criticism about the court itself as an institution that corrupts all those who approach it. Alongside the customary censure of the banality of the entertainments and clothing of courtiers in part one, we now find severe judgments condemning the courtiers' vices, as well as a strong indictment of the social configuration of the court that brings about the moral degradation of individuals.

The austere government of the late Philip II, usually symbolized by El Escorial, had transitioned under Philip III to the careless and trivial entertainments more associated with houses of pleasure- "casas de placer" - as the narrator dubs the palace of the Duke and Duchess in part two (2.31:273). Most critics agree that the reader of the time was very likely to have made the connection between this "house of pleasure" and the "corte de recreo" created by the Duke of Lerma for the King, due to the excesses that often took place in their celebrations. From the beginning, Lerma had been very active in devising a "courtiers' court" and created "cortes de recreo" in places such as the town of Lerma, where the King could be sheltered from court officials and the responsibilities of government. The celebrations often lasted for days and seemed to populate the calendar of the royal court as a means of diverting the attention of the monarch from reality and keeping him 
ignorant of the complaints of his people, of the bankruptcy of the state, of the miserable life of the soldiers, merchants, and artisans, and of the general collapse of the Imperial project.

For these reasons, the apocryphal courtier-knight described by Avellaneda is presented as a mere reversal of Don Quixote, and as a parody of the heroic nobility where he was supposed to find his roots and his source of auctoritas. The numerous jousts, tourneys, games of chivalric competition, bull fighting, hunting, and parades of nobles that Philip III promoted are seen as in Cervantes's second part as nothing but a dream, a diversion, and in some cases, a poisonous illusion. In this subversive second part, Don Quixote understands that the sophisticated and expensive clothes that courtiers wear with pride are instead billboards of their shame. And he exposes this shame from the very start of the second part:

Los más de los caballeros que agora se usan, antes les crujen los damascos, los brocados y otras ricas telas de que se visten, que la malla con que se arman; ya no hay caballero que duerma en los campos sujeto al rigor del cielo [...] Ya no hay ninguno que en saliendo de este bosque entre en aquella montańa [...] Mas agora ya triunfa la pereza de la diligencia, la ociosidad del trabajo, el vicio de la virtud, la arrogancia de la valentía. (2.I:48)

Cervantes does not stop here, however. He uses the long stay of Don Quixote and Sancho Panza at the ducal palace as a way to examine current court behavior. From the very beginning, when Sancho and his master first meet the Duchess (and, shortly thereafter, the Duke), they are immediately recognized as the characters from the first part and invited to the palace. The intention of the Duke and the Duchess is solely to be entertained at the expense of the misery, ignorance, and illness of Don Quixote. During their stay, Cervantes's knight-errant and his squire are made fun of in a variety of ways, ranging from essential hygienic customs such as the washing of Don Quixote's beard to the dangers of the explosion of fireworks hidden inside Clavileño. 
Entertaining one's own court was indeed an obligation for the king or the nobleman, but it was to be done in such a way that it would showcase his patronage of artists, writers, and musicians, rather than humiliate the uneducated or make fun of the ill. Jokes and mockeries, according to the books of courtesy, should not be enacted among those of unequal standing, nor should these jokes threaten their dignity. This is obviously not the case in Don Quixote. Baldassare Castiglione's Cortegiano suggests that "le burle del Cortegiano par che si debbano allontanar un poco più dalla scurilità... E che non siano anco troppo acerbe" (II, \$89; 246). And, in general terms, Castiglione, Milán, Cristóbal de Villalón, and Lucas Gracián Dantisco all agree on the necessity of courtiers to avoid being involved in any sort of wicked mockery. ${ }^{2}$ However, throughout Don Quixote's stay at the palace we constantly see the degeneration of the humanist model that inspired the creation of both the Renaissance court and the role of courtiers. Ideally, this court and its philosophical courtiers would help the prince to make right and just choices. At the court represented in Don Quixote, however, the Duke prefers to hear the schemes prepared by the domestic servants more than the advice of the educated priest in residence.

In Ragion di Stato (1589), Giovanni Botero explains the consequences of adhering to Machiavellian principles, according to which, power - the ultimate goal of political activity - has its own set of ethical rules, rules not necessarily guided by personal morals, the common good, or religious conventions. While medieval political theory insisted that the main goal of a Christian prince was to defend "good" and fight "evil," this was no longer valid for the modern, Machiavellian world. Now, a good ruler was not to be guided by a moral compass. Instead, before he took any action, he needed to evaluate its "usefulness" and calculate all possible consequences. He should assess how his decision would contribute to the state's strategic interest, predict the strength and possible resistance of the enemy, and ascertain the political consequences. When this modern notion of political power was placed on the shoulders of members of the different councils, ad-hoc

2 Of course, these same authors also stress the appropriate use of jokes and witticisms as a way to gain honor and respect. See Schmitz (45I-52). 
committees (juntas), and courtiers, such groups would apply the same ethical principles of the 'ragion di stato' to their domestic rivalries.

Consequently, their decisions and actions would not be led by an understanding of the common good, the state, or even the king, but instead by personal interests. Selfishness, simulation, and caution then became the most valuable virtues of the modern courtier.

It was, however, still customary for the king or the noble to have in his court a reputable priest who could provide him with moral advice. In Don Quixote, the Duke and the Duchess did have just such a priest in their court, but his role is reduced to a bare minimum. The priest reprimands his master for his reading of the first part of Don Quixote by telling him that "era disparate leer tales disparates," but the Duke continuously ignores his advice (2.31:28I) ${ }^{3}$ Finally, unable to gain the respect of the Duke, the cleric leaves the palace and accuses his master of being even crazier than both Don Quixote and his squire:

Por el hábito que tengo, que estoy por decir que es tan sandio vuestra excelencia como estos pecadores. ¡Mirad si no han de ser ellos locos, pues los cuerdos canonizan sus locuras! Quédese vuestra excelencia con ellos; que en tanto que estuvieren en casa, me estaré yo en la mía, y me escusaré de reprehender lo que no puedo remediar. (2.31:284)

With the priest gone and nobody else to take the moral helm of the court, the Duke and Duchess, their officials, and their servants turn their backs on any sense of ethical values that might have prevented them from performing cruel and wicked mockeries of Don Quixote and Sancho. Cervantes, now, can proceed to describe the outcome of a court whose sole purpose is to be a "corte de entretenimiento" with no responsibilities towards the republic and no limit to their general appetite for entertainment. This situation mirrors the other "courtiers'

3 Of course, we also know that the Duchess has read and knows the first part fairly well. She refers to it by its complete title and then discusses with Sancho some very specific details of the story $(2.30: 270 ; 2.33: 297)$. 
court" created in his town of Lerma by Francisco Gómez de Sandoval y Rojas, Duke of Lerma, for King Philip III.

Court societies were to be governed by a number of more or less strict regulations that curtailed improper behavior on the part of their different members. Their interactions defined—and, at the same time were defined by - the status of the courtiers. The goal of any courtier was to climb the social ladder in order to reach a position in which he or she could enjoy the "privanza," the confidence of the master. As Elias asserts, the strength of the king or the lord lies in knowing how to manage these tensions and competitions in order to gain favor and use them for his own benefit. Similarly, when a king or lord is not able to control the actions and intentions of the people of his own court, his weakness is evident. And, as Don Quixote explains to Sancho shortly after their arrival at the ducal palace, "en tanto más es tenido el señor cuanto tiene más honrados y bien nacidos criados [...]. ¿№ adviertes, angustiado de ti, y malaventurado de mí, que si veen que tú eres un grosero villano o un mentecato gracioso, pensarán que yo soy algún echacuervos, o algún caballero de mohatra?" (2.31:277). Such a concern, however, does not seem to be in the minds of the Duke and Duchess with regard to their servants.

In Grilli's "novela de los duques," the servants act without the knowledge or permission of the Duke. At the beginning of the adventures in the palace, a maid washes Don Quixote's beard after he has finished his first meal, and the narrator informs us that "[e]l duque y la duquesa, que de nada desto eran sabidores, estaban esperando en qué había de parar tan extraordinario lavatorio" (2.32:286). Since medieval times, the rubbing of one's beard had been considered an offense to one's manhood. Through the work of Elias we also know that the protocol at the table was a means to both control different tensions in the court palace and to display the court hierarchy at the table. The banquet, with its complex rules of etiquette, was also one of the most important moments in which courtiers had the opportunity to showcase visible signs of a distinguished behavior that separated their class from the common people. Meals were a way of honoring a guest by 
introducing him into the prince's inner circle and symbolically sharing his bread. Elias explains that in court society one is honored and continues to partake in aristocratic society "only as long as the others think him a member," and one had honor "as long as one was deemed a member by the society and so by one's own consciousness. To lose one's honour was to forfeit membership of 'good society'" (Court IO4). In the episode of the washing of the beard, the true identity of the hidalgo Alonso Quixano_-already known to the courtiers, who are aware of his condition and misfortunes in part one-is erased in favor of the character Don Quixote, who, by being made fun of by a maid, is then lowered to the level of a servant. ${ }^{4}$ This situation is even more reprehensible for the Duke when, willing to sacrifice his own dignity just to be able to continue the charade, he asks the maid to also wash his beard so that Don Quixote may not realize the offense: "la muchacha, aguda y diligente, llegó y puso la fuente al duque como a Don Quijote, y dándose prisa, le lavaron y jabonaron muy bien, y dejándole enjuto y limpio, haciendo reverencias se fueron" (2.32:287).

Following this meal, the Duchess takes Sancho to her chambers. Elias Rivers has noted the class difference between Sancho and the Duchess, and makes this encounter an implausible episode (38). A woman of her status would never have invited to her chambers a man from a class so much lower than hers. However, if we accept that Sancho entered into the chamber to pass the early afternoon in conversation with the Duchess and her "doncellas," then we witness just one more way in which a short period of time at court, and the desire to please someone of higher status, can break what was considered an almost sacred bond: the loyalty that united a squire with his knight. The Duke breaks this bond physically by sending Sancho off to the Insula de Barataria; but before that, it is broken spiritually by the Duchess when she teaches Sancho the courtesan "virtue" of revealing secrets and

4 Luis Andrés Murillo, following Juan Antonio Pellicer, considers this story similar to one involving a Portuguese ambassador at the count of Benavente's palace (2.32:287ni2). The main difference, however, is that while in the historical anecdote the jest is planned by the count himself, the episode in Cervantes's narrative is planned and executed by the maid. The dishonor lies in the fact that it is a maid mocking an hidalgo and not in the action itself. 
gossiping at the expense of his master. Sancho becomes a confidanta "privado" - of the Duchess, to whom he confesses: "Ahora, señora mía, que he visto que no nos escucha nadie de solapa [...] lo primero que digo es que yo tengo a mi señor Don Quijote por loco rematado" (2.33:297).

With Sancho on their side, the Duke tries to convince Don Quixote to join their lifestyle by celebrating banquets in his honor, trying to cajole him into dressing according to the customs of the court and to conduct himself as a courtier-knight, which he refuses (2.34:304-05). Don Quixote is the only character in this court (including courtiers, officials, servants, and Sancho) whose sense of ethics resists decay and who, despite the temptations, avoids becoming a "perezoso cortesano que antes busca nuevas para referirlas y contarlas, que procura hacer obras y hazańas para que otros las cuenten y las escriban" (2.36:325). And he does so even when he is invited to enjoy noble pastimes such as enclosed hunting, in which the Duke finds his highest pleasure. For the Duke and the high society of the time, this activity was a noticeable mark of his high nobility, since this sort of hunting "no es para todos, como lo es el de otros géneros de caza, excepto el de la volatería, que también es sólo para reyes y grandes señores" (2.34:307).

Within the space of just three chapters, then, the Duke and Duchess have given four important signs of their uncourtliness by losing control over their servants, mocking their guests, attempting to corrupt them, and breaking the bond between a knight and his squire. Later on they will further show their irresponsibility when they effectively give the government of a section of their estate over to Sancho Panza as a mockery. This later scheme is designed only for the servants to enjoy, since no other nobleman of the court moves to the "island" of Barataria where Sancho is appointed as governor. In summary, with these actions, the Duke and Duchess seem to model the old Latin saying, "corruptio optimi pessima," and the unscrupulous masters corrupt their servants by making them accessories to the cruel jokes they play on Don Quixote at their "casa de placer" and on Sancho in the Barataria episode.

But this court does not stop at just these mockeries. The Duke and Duchess's diversion from responsibility in their constant search for 
entertainment becomes even more negligent when we learn that dona Leonor-the Duchess's "duenna of honour"-feels compelled to approach Don Quixote, crying for help because a squire has dishonored her daughter and the Duke and Duchess are refusing to do her justice because they owe money to the offender's master:

En resolución, desta mi muchacha se enamoró un hijo de un labrador riquísimo que está en una aldea del duque mi señor, no muy lejos de aquí. En efecto, no sé cómo ni cómo no, ellos se juntaron, y debajo de la palabra de ser su esposo, burló a mi hija, y no se la quiere cumplir; y aunque el duque mi seńor lo sabe, porque yo me he quejado a él, no una, sino muchas veces, y pedídole mande que el tal labrador se case con mi hija, hace orejas de mercader y apenas quiere oírme; y es la causa que como el padre del burlador es tan rico y le presta dineros, y le sale por fiador de sus trampas por momentos, no le quiere descontentar, ni dar pesadumbre en ningún modo. (2.48:402)

It is here where we see that this noble court has failed in its very essence: it refuses to shield the honor of those who live under the protection of the Duke and Duchess. As was the case of Philip III's court, the court depicted in this novel is one of luxury, spectacle, and public festival funded by expenditures from a dwindling treasury. And when this treasury is exhausted, so too is any sense of medieval justice (such as defending the "good" and fighting "evil"). It is a small step to take from ragion di stato to plain personal convenience, and the Duke does not hesitate to take it. The modern ruler was supposed to weigh the practical consequences of his actions in order to determine what course of action might be more beneficial to the state as a whole. Yet, the Duke weighs the harm that siding against his creditor would cause to his own estate, and decides to shirk his responsibility to protect the honor of a young lady who was raised in his house.

In I6I5, Philip III-much like the Duke in Don Quixote-was facing an increasing debt. Juan de Mariana had advised him in his De moneta mutatione (1609) to cut excessive spending and reduce the public 
dimension of the majesty of his persona. Mariana claimed that, at that particular time, moderation would be more splendid and would manifest more majesty than unnecessary and unseasonable consumption. Additionally, he suggested that this measure would not involve any injury to or resentment of the nation. However, when the Inquisition arrested Mariana and charged him with lèse-majesté for criticizing the monetary policy of the King (including his book on the Spanish Index), the Duke of Lerma and Philip III showed just how far they had come from wanting to serve the common good of the people. ${ }^{5}$

Cervantes, like most of the war veteran writers of the Spanish Golden Age, had very low regard for courtiers who, in their eyes, spent frivolously the gold that was earned with soldiers' blood. Don Quixote expresses this sentiment well when comparing the knight-errant to the courtier, describing the only duties of the courtier as follows:

[S]irva a las damas el cortesano; autorice la corte de su rey con libreas; sustente los caballeros pobres con el espléndido plato de su mesa; concierte justas, mantenga torneos, y muéstrese grande, liberal y magnífico, y buen cristiano, sobre todo, y desta manera cumplirá con sus precisas obligaciones. (2.17:167)

Courtiers of this time were often criticized for their affected behavior and flamboyant fashion, manifesting a certain gender ambiguity in their ostentatious clothing, wigs, and makeup. Preachers and traditionalists of the time used this new standard for masculinity in their sermons as proof of the decadence of Spanish power in Europe. They defended the return to the austere manhood of Philip II's court as a way to restore the values that had made the kingdom great (Maravall 93-96). While Cervantes had already criticized the courtiers in part one, in part two, and particularly in the "novela de los duques," he goes several steps beyond those attacks towards a more structural critique. For him, it is the configuration of the court as a social institution that

s On Mariana, see Vilches (258-63). 
irremediably lowers the ethical code of the nobility, corrupts the brave, and damages the realm.

The kind of harsh-and more structurally defined — criticism written by Cervantes in his later years is not unique to the second part of Don Quixote. It can also be seen in the short stories of his Novelas ejemplares (1613), such as "La española inglesa," wherein he writes that "no hay merced que el príncipe haga a su privado que no sea una lanza que atraviesa el corazón del envidioso" (I: 262), and where Count Arnesto and his mother-lady-in-waiting for the Queen of England-scheme together against Captain Ricaredo. Moreover, in his posthumous Los trabajos de Persiles y Sigismunda (1617) we also find several cases of corruption in the court. Most notably, Policarpo is elected king because he is considered the most virtuous man among the people of his island, deemed fit to rule until his passing or until his character fails. In this episode, however, Policarpo and his daughter fall in love with the protagonists of the novel, and, blinded by their love, they resort to schemes and seek the aid of a sorceress to hold both Auristela and Periandro captive.

Beyond the cases examined in this essay, there are many more Cervantine passages that share one common denominator: the court as an environment that fosters moral decay and corrupts the optimi. We have seen that in the interim between the publication of part one and part two of Don Quixote the royal court had come to require an unwarranted amount of time and resources that were much needed in other areas of the government. Witnessing these societal changes and experiencing them in his life, Cervantes's opinion and his textual representations of the court changed as well, from merely casual criticisms of individual courtiers to more crude representations of the harrowing effects the aulic institution had on society as a whole. The character of Don Quixote was quickly assimilated into the courtly entertainments, "aventuras," and bullfights in the numerous festivals organized by the Duke of Lerma for Philip III at his "casa de recreo." Thus, when Cervantes incorporates Don Quixote into the "chivalric" entertainments at the "casa de placer" of the Duke and Duchess of the novel, it is symbolic of the loss of the values that this knight-errant, and the 
warrior-knight, once represented and which are now, much like the armor of Alonso Quixano, "tomadas de orín” (I.I:75).

\section{i_lopez@uncg.edu \\ University of North Carolina, Greensboro}

\section{Works Cited}

Armstrong-Roche, Michael. Cervantes' Epic Novel: Empire, Religion, and the Dream Life of Heroes in Persiles. Toronto: U of Toronto P, 2009.

Bouza, Fernando. "La majestad de Felipe II: Construcción del mito real." La corte de Felipe II. Ed. José Martínez Millán. Madrid: Alianza, 1994. 37-72.

Castiglione, Baldessar. Il libro del Cortegiano. Ed. Michele Scherillo. Milano: Ulrico Hoepli, 1928.

Cervantes, Miguel de. El ingenioso hidalgo Don Quijote de la Mancha. Ed. Luis Murillo. 2 vols. 5 th ed. Madrid: Castalia, I99I.

—. Los trabajos de Persiles y Sigismunda. Ed. Carlos Romero Muñoz. 5 th ed. Madrid: Cátedra, 2004.

—. Novelas ejemplares. Ed. Harry Sieber. 2 vols. I7th ed. Madrid: Cátedra, 1995.

Close, Anthony. "Cervantes: Pensamiento, personalidad, cultura." Don Quijote de la Mancha. Ed. Francisco Rico and Joaquín Forradellas. Barcelona: Crítica, I998. lxvii-lxxxvi.

Crespo López, Mario. "Cervantes y la corte: Apuntes biográficos, sociopolíticos y culturales de las relaciones áulicas de Cervantes." Boletín de la Biblioteca Menéndez Pelayo 76 (2000): 63-145.

Elias, Norbert. The Civilizing Process. Trans. Edmund Jephcott. Oxford: Blackwell, 2000.

- The Court Society: Collected Works of Norbert Elias. Vol. 2. Trans. Edmund Jephcott. Dublin: U College Dublin P, 2006.

García García, Bernardo J. "Las fiestas de la corte en los espacios del valido: La privanza del duque de Lerma." La fiesta cortesana en la época de los Austrias. Ed. María Luisa Lobato and Bernardo J. García García. Valladolid: Junta de Castilla y León, 2003. 34-77.

Grilli, Giuseppe. "La corte de los duques: Quijote II, 30-33 (al fondo el Tirante, el palacio de Constantinopla y sus fiestas)." Edad de Oro I5 (1996): 4I-6I.

Iffland, James. De fiestas y aguafiestas: Risa, locura e ideología en Cervantes y Avellaneda. Madrid: Iberoamericana, 1999. 
Llull, Ramón. "Libro de la Orden de Caballería." LA ORDEN DE CABALLERIA, anónimo del siglo XIII. LIBRO DE LA ORDEN DE LA CABALLERIA, Ramón Llull. Ed. and transl. Javier Martín Lalanda. Madrid: Siruela, 2009. 63-103.

Mades, Leonard. The Armor and the Brocade: A Study of DON QUIXOTE and THE COURTIER. New York: Las Americas Publishing, 1968.

Maravall, José Antonio. La cultura del Barroco. 8th ed. Barcelona: Ariel, 2000.

Milán, Luis. Libro intitulado El Cortesano. Valencia, $156 \mathrm{r}$.

Pérez, Joseph. The Spanish Inquisition: A History. Trans. Janet Lloyd. New Haven: Yale UP, 2005.

Rey Hazas, Antonio. "El Quijote y la picaresca: La figura del hidalgo en el nacimiento de la novela moderna." Edad de Oro is (1996): 141-60.

Rivers, Elias L. "Sancho y la duquesa: Una nota socioliteraria." Cervantes II.2 (199I): $35-42$.

Schmitz, Ryan. "Sancho's Courtly Performance: Discreción and the Art of Conversation in the Ducal Palace Episodes of Don Quixote II." MLN I28.2 (2013): 445-55.

Sieber, Harry. "The Magnificent Fountain: Literary Patronage in the Court of Philip III." Cervantes 18.2 (1998): 85-116.

Vilches, Elvira. New World Gold: Cultural Anxiety and Monetary Disorder in Early Modern Spain. Chicago: U of Chicago P, 2010. 